\title{
Assessing Groundwater Quality for Multiuse and Geochemical Evolution in the South Banat Area of Serbia, Pannonian Basin
}

\author{
Brankica Majkić-Dursun*, Ivana Oros, Ilija Oparušić, Anđelka Petković \\ Jaroslav Černi Water Institute, Belgrade, Serbia
}

Received: 3 June 2018

Accepted: 7 August 2018

\begin{abstract}
The study includes an assessment of groundwater quality from one shallow and two deeper aquifers in the Danube left bank, under the conditions of coexistence of the open coal mine, arable lands with increasing irrigation needs and potential regional water supply system for the Banat region. The spatial distribution maps of the targeted parameters were used as a starting point in the identification of nine zones in the study area. The Piper plot and the specific ionic plots pointed out that dissolution of carbonate and silicate minerals, as well as cation exchange, plays a significant role in the groundwater chemistry. Although the geological and hydrogeological complexity of the study area highlighted the considerable vertical and horizontal zonations when it comes to groundwater quality, waters have a desirable quality for drinking while for irrigation the eastern zone of the study area is better. Vertical mixing of shallow and deeper groundwaters confirmed the post-sedimentary faulting and erosion of coal seams in the central part of the study area. Generally, the results of determining the origin and quality of groundwaters throughout the study area could greatly help in making decisions regarding the regional water supply and expansion of irrigated lands in the future.
\end{abstract}

Keywords: ionic content, hydrochemical zonation, multipurpose groundwater use, quality index

\section{Introduction}

Groundwater constitutes the largest reservoir of freshwater in the world (excluding glaciers and ice caps); thus it is major source of potable, agricultural and industrial water. According to the International Groundwater Resources Assessment Centre (IGRAC) [1], groundwater provides almost $50 \%$ of all drinking water worldwide, about $40 \%$ of water for irrigated

*e-mail: brankica.majkic-dursun@jcerni.rs agriculture and about $30 \%$ of water supply required for industry. Similar to the majority European countries, the contribution of groundwater to the water supply in Serbia is around $70 \%$, of which more than $50 \%$ comes from alluvial aquifers [2]. These valuable resources are under increasing pressure due to different human activities (including population- and wealth growth) and climate change [1].

The water supply in the northern part of Serbia, Province of Vojvodina, depends only on groundwater resources [3]. Municipal and industrial water supplies in Vojvodina rely entirely on groundwater abstractions from the three types of aquifers: alluvial aquifers, the 
main water-bearing complex (WBC), and Pliocene aquifers. In the Banat area water is tapped from the shallow "first" aquifer in southeastern Banat (depth to $25 \mathrm{~m}$ ), while the depth of abstracted water increases in the north, where the groundwater originates from WBC $(230 \mathrm{~m})$ or Pliocene water-bearing strata. In the deeper aquifers recharge is very slow and under the pressure of over-exploitation (especially in the north Banat region) and current abstraction rates exceed sustainable yield [4]. Groundwater chemical compositions are controlled by the geological and hydrogeological conditions of the water-bearing strata, and in the numerous cities are inadequate for human consumption [3]. The Water Master Plan (WMP) of the Republic of Serbia [5] addresses the issues of the organized water supply in the Banat region. The problem could be resolved through the creation of a regional water supply system at the KovinDubovac area with 42 new radial wells, which were supposed to be drilled about $50 \mathrm{~m}$ from the dike toe, in line with the Danube River near Dubovačka Ada and the open pit. This regional water supply system would connect 16 municipalities in the Banat. The raising of the groundwater table in the study area is caused by the Iron Gate Hydro Power and Nautical System (Iron Gate HPNS). Both systems significantly modified the Danube river regime and caused a number of issues concerning water management decisions, as well as agricultural production in the riparian belt [6]. Almost 300 drainage wells (DWs), dykes and branched drainage ditches network, are needed to maintain groundwater levels at pre-defined depths in order to protect further inland from the impact of Iron Gate 1HPP reservoir.

Additionally, Kovin is one of the most important Upper Miocene coal basins in Serbia and has great economic importance as a source of energy production. The Kovin coal basin is divided on western "Field A" $\left(16.3 \mathrm{~km}^{2}\right)$ and eastern "Field B" $\left(23.7 \mathrm{~km}^{2}\right)$ [7]. According to the official data, lignite resources in the Kovin area are estimated at $275 \mathrm{Mt}$.

Although agriculture has been an important part of Serbia's economy, and cropland occupies almost $70 \%$ of the country, only a small percentage of arable land is irrigated [8]. Kovin-Dubovac is an important agricultural region with sparsely irrigated lands. A smaller area of irrigated lands is located in the central part of the Kovin-Dubovac depression south of Gaj village, while larger irrigated lands are situated to the north, between Kovin and Deliblato. WMP [5] projects that by 2021, total irrigated land will amount up to 11 050 ha.

There is an important need to improve the understanding of existing groundwater resources for an effective strategy of their use by different users. A geochemical analysis provides a better insight of possible variation of groundwater quality as development process, and those results could be useful for determining its suitability for different purposes [9].

This study represents an effort to characterize the origin of groundwater from different water-bearing layers, possible interlayer connections, and suitability of groundwater for different purposes (irrigation, water supply and industry). The estimation of groundwater quality and development of strategies for protection of aquifers from contamination are essential aspects of water resource management.

\section{Description of the Study Area}

The Kovin-Dubovac area is located in the southern part of the Pannonian basin, on the left bank of the Danube River (Fig. 1a). This area covers approximately $100 \mathrm{~km}^{2}$ of the alluvial plain, between Gaj and Varoška terrace on the north, the city of Kovin to the west, Dubovac village to the east and the Danube River to the south (Fig. 1b). Also, the area involves lowlands with altitudes of from 67 to $71 \mathrm{~m}$ a.s.l. In southeast Banat, Middle Miocene (Sarmatian) deposits consist of clayey marlstone interbedded with very thin layers of marly-clay, clayey sandstone, sand, and gravel [7]. In the horst structure of Kovin-Gaj the basement beds are overlaid by Pannonian marly-clays, marls and clays [10, 11], while in the Kovin coal deposits area, Pannonian sediments consist of caspibrackish grey and white marlstone with a rare thin layer of clay and silt with two lignite seams [12]. Pannonian beds (Fig. 1c) are overlaid by lower (marls, silts, and fine-grained sands and clays sporadically with very thin lignite interlayer) and upper Pontian deposits (with three productive lignite seams) [13] (Fig. 1c). Upper Pontian deposits could be divided into two facies: Kostolac and Danubian (Fig. 1b). Coalbearing Pontian sediments are made up of loosely bounded sand with three coal seams (upper-Ia and Ib, middle-II, and deep settled-III) of uneven thickness. In the central part of Kovin depression the lignite seams create an antiform due to post-sedimentary faulting, which causes layers to be partially eroded, whereas in the western and eastern parts seams are deeper settled (Field B) or depleted [13, 14]. Pontian deposits, which are overlaid by freshwater Paludina beds (Fig. 1c), consisting of clays and silts in lower, and sands, silts and clays in upper parts, are discovered in the area of the Deliblato dune. Polycyclic-fluvial (Qf) and fluvial-marshy (Qm) deposits eroded in the Kovin depression [11], and the youngest Upper Pleistocene and Holocene sediments, are overlaying older ones (Fig. 1c). The younger alluvial terrace $\left(\mathrm{Qt}_{2}\right)$, Varoška terace (Fig. 1c), formed during the Upper Pleistocene/Holocen, presents the north border of the Kovin-Dubovac area (Fig. 1b). The fluvial deposits constitute the youngest formation (Qa) and cover the largest part of the Danube alluvial plain (Figs $1 \mathrm{~b}$ and 1c). They have proven to be the good collectors of groundwater $[2,4,11,15]$. The lower part of those sediments is comprised of gravels and sandygravels whose grain sizes vary to a large extent. This sequence of sediments ends with semi-permeable silts, silty-sands, silty-clays, and clays. The thickness of the gravels and sands in the Danube riparian is 15 to $20 \mathrm{~m}$ 


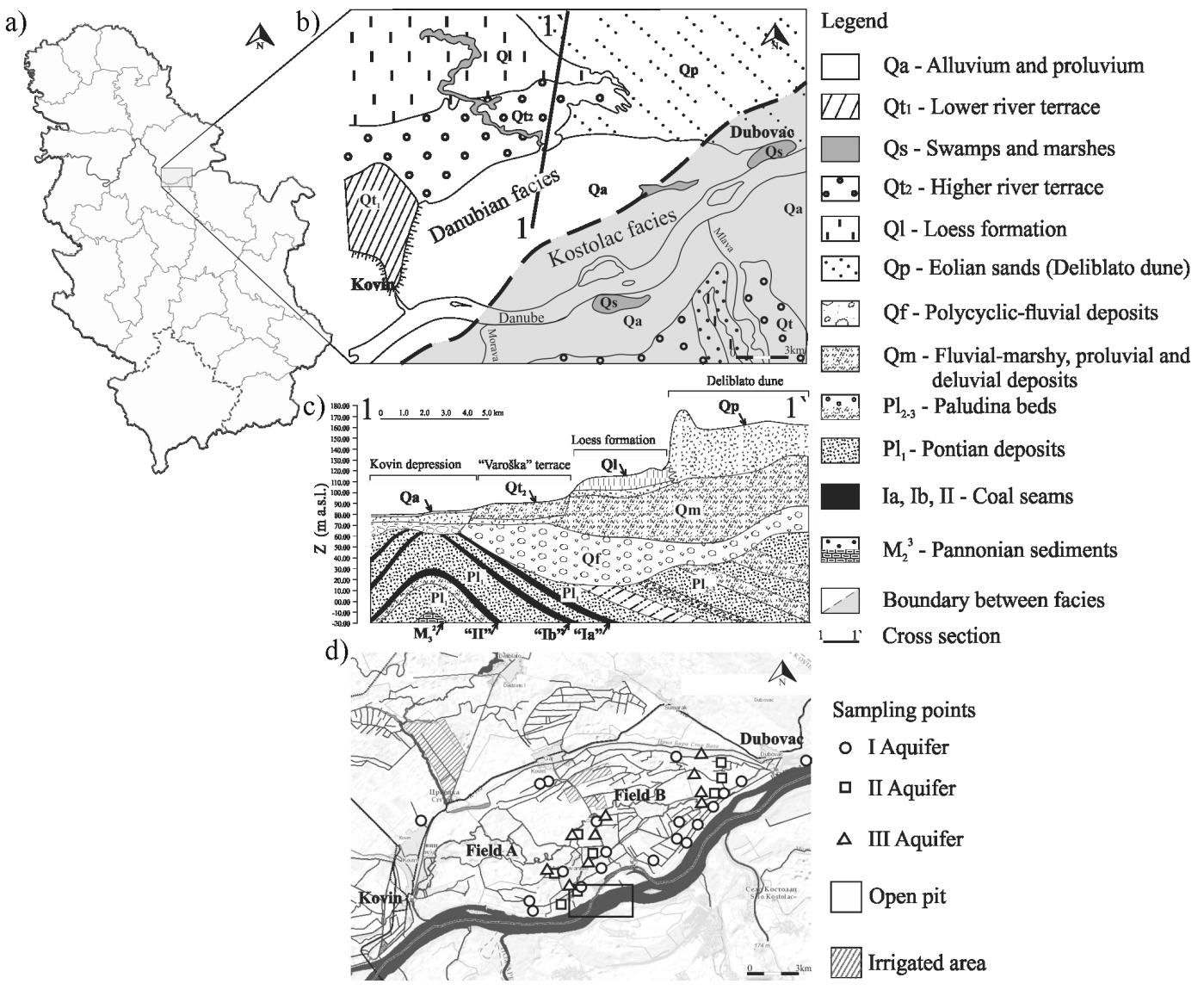

Fig. 1. Position of study area, geological map, geological cross-section and locations of coal mine, observed sampling points [10, 11, 13]-modified.

(locally up to $30 \mathrm{~m}$ ), while the thickness of the semipermeable layer is up to $7 \mathrm{~m}[15]$. The area of KovinDubovac alluvial plain has several alluvial aquifers and groundwater levels are relatively shallow (several meters from the ground). The "first aquifer" (I) occurs in Quaternary gravels and sandy-gravels. Deeper, subartesian aquifers (II and III) have been formed in older Pontian sands. Permeability coefficient is estimated at from $1.4 \times 10^{-3}$ to $2.4 \times 10^{-2} \mathrm{~m} \mathrm{~s}^{-1}$ for aquifer I in the zone near the coal pit, and decreases to the north ( 0.5 to $2 \times 10^{-3} \mathrm{~m} \mathrm{~s}^{-1}$ near the northern border)-and with depth ( $\mathrm{x} \times 10^{-4}$ to $10^{-5} \mathrm{~m} \mathrm{~s}^{-1}$ for the sands of III aquifer) [13].

\section{Material and Methods}

Several hydrochemical sampling campaigns were performed on the Kovin-Dubovac area over the last seven years. Each campaign usually includes two sampling series: spring-summer and autumn. The first campaign was conducted during the 2010-2013 period on the 12 drainage wells, including the I aquifer, while the eight piezometers were monitored in the 2013-2014 period (Fig. 1d). Sampling campaigns of the deeper groundwater aquifers were executed in 2015-2016 on 18 more piezometers (Fig. 1d). A set of 128 groundwater samples was analyzed for 13 physico-chemical parameters: major cations and anions concentrations $\left(\mathrm{Na}^{+}, \mathrm{K}^{+}, \mathrm{Ca}^{2+}, \mathrm{Mg}^{2+}, \mathrm{Cl}^{-}, \mathrm{SO}_{4}^{2-}\right.$, and $\left.\mathrm{HCO}_{3}^{-}\right)$, electrical conductivity (EC), $\mathrm{pH}$ value, groundwater temperature (T), alkalinity, total hardness (TH), and silica content. The total dissolved solids (TDS) were estimated using the calculation method. Groundwater levels were also measured. Groundwater level, temperature, $\mathrm{pH}$ value and electrical conductivity were measured in-situ (SEBA multi-parameter with dedicated sensor probes), whereas all of the other parameters were determined in the laboratory using the Standard Methods for the Examination Water and Wastewater practice (SMEWW) [16]. The accuracy of the chemical analysis was verified through the calculation of ion-balance errors; and the errors were less than $10 \%$.

\section{Data Analysis}

The initial step in the data analysis involved spatial distribution of hydrochemical parameters (SURFER 8.0 software) through the spatial distribution maps in order to divide the Kovin-Dubovac area into the appropriate zones.

The hydrochemical classifications of groundwaters were determined based on the Piper trilinear diagram and the plots of ionic relations $\mathrm{Ca}^{2+}+\mathrm{Mg}^{2+}$ versus total 
cations, $\mathrm{Ca}^{2+}+\mathrm{Mg}^{2+}$ versus $\mathrm{HCO}_{3}, \mathrm{Ca}^{2+}+\mathrm{Mg}^{2+}$ versus $\mathrm{Na}^{+}+\mathrm{K}^{+}, \mathrm{Cl}^{-}$versus $\mathrm{Na}^{+}$, and $\mathrm{Na} / \mathrm{Cl}$ versus EC.

Pearson correlation analysis was performed in order to identify correlations between the targeted hydrochemical parameters $\left(\mathrm{Na}^{+}, \mathrm{K}^{+}, \mathrm{Ca}^{2+}, \mathrm{Mg}^{2+}\right.$, $\mathrm{HCO}_{3}, \mathrm{Cl}^{-}, \mathrm{SO}_{4}^{2-}, \mathrm{SiO}_{2}$ and TDS) (SPSS Statistics 22.0 software). The suitability of groundwater for irrigation, water supply and industrial purposes was evaluated through the calculation of the sodium adsorption ratio (SAR), percent sodium $(\% \mathrm{Na})$, residual sodium carbonate (RSC), Kelly's ratio (KR), and magnesium adsorption ratio (MAR), as well as Langelier saturation index (LSI), Ryznar stability index (RSI), and aggressive index (AI).

\section{Results and Discussion}

\section{Hydrochemical Classification of Groundwater}

Table 1 contains the main descriptive statistics of the monitored hydrochemical parameters. Median $\mathrm{pH}$ values of groundwater samples range from 7.5 to 8.4 , indicating an increase of $\mathrm{pH}$ with the depth and suggesting a shift from neutral to alkaline conditions. Groundwater temperature was relatively constant with median values ranging from 13.3 to $14.5^{\circ} \mathrm{C}$. The higher standard deviations of EC and TDS values (Table 1) reflect the wide vertical and spatial variability in ionic concentrations in the groundwaters of the KovinDubovac area, which could be attributed to the different mineralogical contents and agricultural activities. Median values of TH suggest that groundwaters belong to the hard waters. Based on the median values of the groundwater samples (Table 1), the order of abundance of the major cations and anions along the entire study area was $\mathrm{Ca}^{2+}>\mathrm{Mg}^{2+}>\mathrm{Na}^{+}>\mathrm{K}^{+}$and $\mathrm{HCO}_{3}>\mathrm{Cl}^{-}>\mathrm{SO}_{4}{ }_{4}^{2-}$.

The correlation coefficients, as the results of Pearson correlation analysis, reveal that the correlations between $\mathrm{Ca}^{2+}$ and $\mathrm{HCO}_{3}^{-}(r=0.789), \mathrm{Mg}^{2+}$ and $\mathrm{HCO}_{3}$ $(r=0.765), \mathrm{HCO}_{3}^{-}$and TDS $(r=0.843)$ are the most significant for the shallow I aquifer. For the II aquifer, strong correlation coefficients are between $\mathrm{Na}^{+}$and $\mathrm{Cl}^{-}$ $(r=0.816), \mathrm{Na}^{+}$and TDS $(r=0.846), \mathrm{Ca}^{2+}$ and $\mathrm{Mg}^{2+}$ $(r=0.873), \mathrm{Ca}^{2+}$ and TDS $(r=0.735), \mathrm{Cl}^{-}$and TDS $(r=0.884), \mathrm{HCO}_{3}{ }^{-}$and $\mathrm{SiO}_{2}(r=0.846)$, and $\mathrm{HCO}_{3}{ }^{-}$and TDS $(r=0.839)$. The III aquifer highlighted the strong correlation coefficients between $\mathrm{Na}^{+}$and $\mathrm{K}^{+}(r=0.765)$, $\mathrm{Na}^{+}$and $\mathrm{Cl}^{-}(r=0.728), \mathrm{Na}^{+}$and TDS $(r=0.754), \mathrm{K}^{+}$ and $\mathrm{Cl}^{-}(r=0.848), \mathrm{K}^{+}$and TDS $(r=0.828), \mathrm{Ca}^{2+}$ and $\mathrm{Mg}^{2+}(r=0.759), \mathrm{Cl}^{-}$and $\mathrm{TDS}(r=0.838)$, and $\mathrm{HCO}_{3}^{-}$ and TDS $(r=0.717)$.

Data presented in Table 1 serve for the graphical display of spatial distribution of target hydrochemical parameters. Spatial distribution maps (Figs 2a-e) illustrate different vertical (three aquifers: I-shallow first aquifer, II-middle aquifer in interlayered sands between Ia - Ib and II coal seams, and III-deeper aquifer formed in older Pontian sands) and horizontal zones (a-western, b-central, and c-eastern) along the Kovin-Dubovac area. According to the spatial distribution of different hydrochemical parameters, the whole area of the KovinDubovac depression is divided into 9 zones: Ia-c, IIa-c, and IIIa-c.

The Piper diagram was used to explain the chemical nature of groundwaters in the Kovin-Dubovac region,

Table 1. Descriptive statistics of analysed hydrochemical groundwater parameters ( $\mathrm{n}=128$ samples).

\begin{tabular}{|c|c|c|c|c|c|c|c|c|c|c|c|c|c|c|c|}
\hline & & \multicolumn{14}{|c|}{ Parameter } \\
\hline $\begin{array}{l}\text { Aqui- } \\
\text { fer }\end{array}$ & & $\mathrm{Na}^{+}$ & $\mathrm{K}^{+}$ & $\mathrm{Ca}^{2+}$ & $\mathrm{Mg}^{2+}$ & $\mathrm{Cl}^{-}$ & $\mathrm{SO}_{4}^{2-}$ & $\mathrm{HCO}_{3}^{-}$ & $\mathrm{EC}$ & $\mathrm{pH}$ & $\mathrm{T}$ & $\begin{array}{l}\text { Alka- } \\
\text { linity }\end{array}$ & $\mathrm{TH}$ & TDS & $\mathrm{SiO}_{2}$ \\
\hline \multirow{4}{*}{ I } & Min & 3.9 & 0.2 & 25.82 & 9.9 & 0.9 & $<\operatorname{LLD}^{\mathrm{a}}$ & 222.4 & 367.0 & 6.7 & 12.4 & 182.3 & 105.4 & 242.2 & 9.6 \\
\hline & Max & 96.4 & 10.6 & 164.44 & 49.0 & 128.2 & 147.8 & 600.9 & $1,078.0$ & 8.4 & 16.2 & 492.5 & 582.0 & 711.5 & 90.2 \\
\hline & Median & 20.2 & 2.0 & 75.51 & 22.7 & 18.2 & 6.7 & 344.0 & 557.0 & 7.5 & 13.2 & 281.2 & 271.1 & 367.6 & 43.4 \\
\hline & SD & 14.9 & 1.7 & 29.23 & 9.1 & 20.1 & 29.0 & 90.6 & 211.8 & 0.3 & 0.8 & 73.4 & 102.7 & 139.8 & 22.2 \\
\hline \multirow{4}{*}{ II } & Min & 7.9 & 1.2 & 13.80 & 5.7 & 0.6 & $<\operatorname{LLD}^{\mathrm{a}}$ & 154.8 & 249.0 & 7.2 & 11.9 & 150.0 & 57.9 & 164.3 & 7.1 \\
\hline & Max & 160.7 & 28.2 & 114.40 & 26.8 & 243.0 & $<\mathrm{LLD}^{\mathrm{a}}$ & 432.5 & $1,238.0$ & 9.0 & 15.7 & 354.5 & 394.6 & 817.1 & 9.6 \\
\hline & Median & 64.5 & 3.4 & 54.05 & 17.5 & 13.0 & $<\mathrm{LLD}^{\mathrm{a}}$ & 320.8 & 598.0 & 8.3 & 14.3 & 276.2 & 206.5 & 394.7 & 8.6 \\
\hline & $\mathrm{SD}$ & 50.4 & 6.8 & 27.47 & 6.4 & 71.9 & - & 89.8 & 307.7 & 0.4 & 0.8 & 69.0 & 92.6 & 203.1 & 1.1 \\
\hline \multirow{4}{*}{ III } & Min & 8.3 & 1.2 & 8.40 & 3.8 & 1.3 & $<\operatorname{LLD}^{\mathrm{a}}$ & 74.0 & 131.0 & 7.4 & 12.3 & 99.0 & 43.3 & 86.5 & 2.7 \\
\hline & Max & 149.8 & 10.4 & 89.40 & 29.3 & 245.1 & 5.6 & 443.5 & $1,112.0$ & 10.0 & 17.7 & 363.5 & 339.5 & 733.9 & 78.1 \\
\hline & Median & 62.9 & 1.9 & 32.75 & 15.5 & 6.1 & 1.0 & 251.7 & 420.5 & 8.4 & 14.5 & 210.0 & 151.6 & 277.5 & 41.8 \\
\hline & SD & 53.9 & 2.6 & 20.11 & 7.6 & 66.2 & 0.9 & 94.5 & 291.1 & 0.5 & 1.4 & 68.2 & 76.7 & 192.1 & 29.3 \\
\hline
\end{tabular}

All parameters are given in $\mathrm{mg} \mathrm{L}^{-1}$ except $\mathrm{EC}\left(\mu \mathrm{S} \mathrm{cm}{ }^{-1}\right), \mathrm{pH}, \mathrm{T}\left({ }^{\circ} \mathrm{C}\right)$ and alkalinity and $\mathrm{TH}\left(\mathrm{mg} \mathrm{CaCO}_{3} \mathrm{~L}^{-1}\right)$.

${ }^{a}$ LLD - low limit detection $\left(\mathrm{LLD}=2.0 \mathrm{mg} \mathrm{L}^{-1}\right)$. 


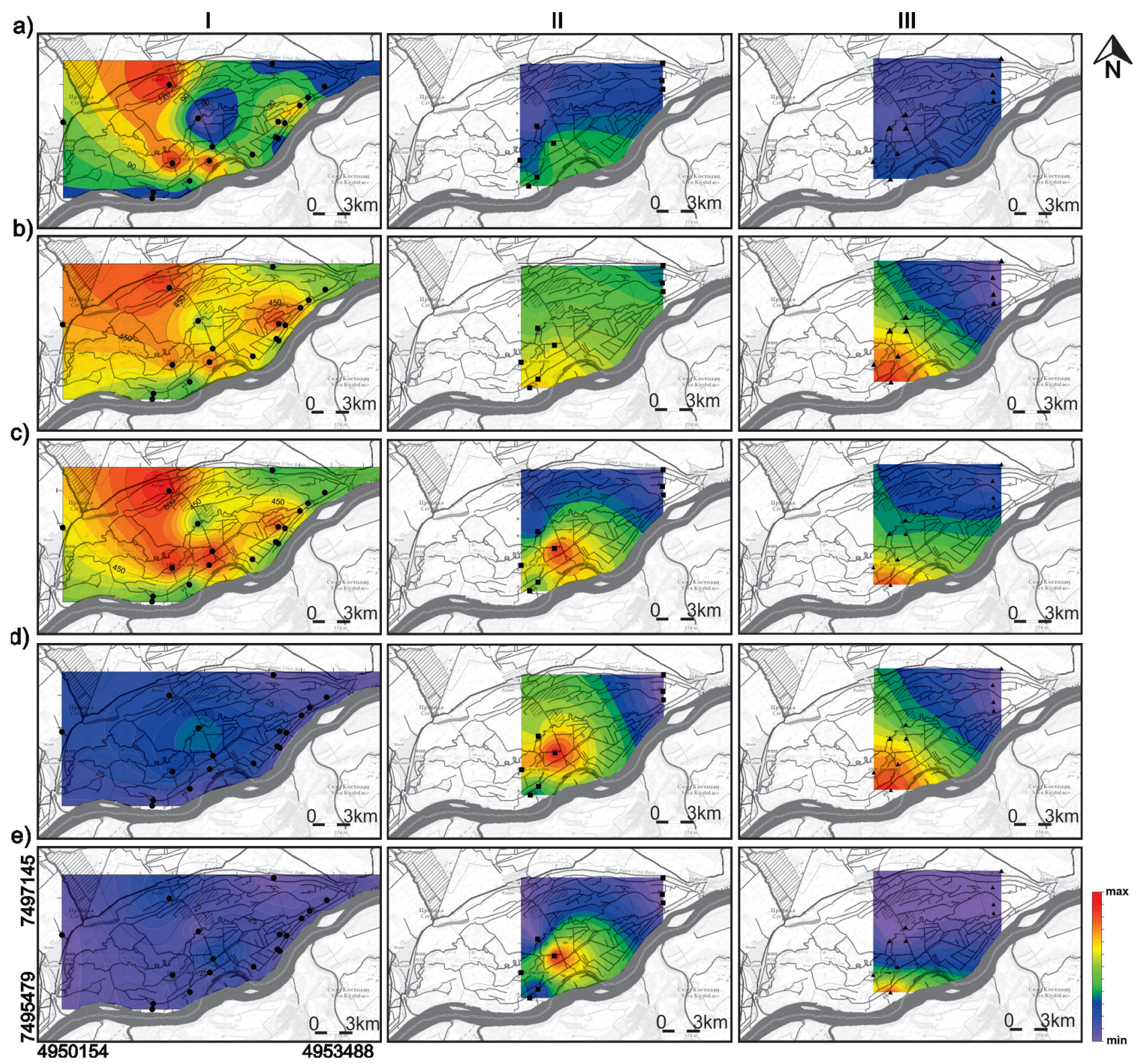

Fig. 2. Spatial distribution of selected parameters $\left.\left(a-\mathrm{Ca}^{2+}, \mathrm{b}-\mathrm{HCO}_{3}^{-}, \mathrm{c}-\mathrm{TDS}, \mathrm{d}-\mathrm{Na}^{+}, \mathrm{e}-\mathrm{Cl}\right)^{-}\right)$in the study area.

describe differences between them, as well as identify the characteristic categories over the study area. A Piper diagram shows that all DWs and piezometers from I aquifer (Ia, Ib, Ic), except DWs from the central part of depression, fall in $\mathrm{Ca}^{2+}$ cation triangle, whereas $\mathrm{HCO}_{3}{ }^{-}$dominates in anion triangle (Fig. 3). The strong correlation coefficients between $\mathrm{Ca}^{2+}$ and $\mathrm{Mg}^{2+}$ with $\mathrm{HCO}_{3}^{2-}, \mathrm{HCO}_{3}^{2-}$ and TDS, are consistent with prevailing hydrochemical type $\mathrm{Ca}^{2+}-\mathrm{HCO}_{3}$. The same chemical type is observed in a deeper aquifer in the eastern part of the study area (Fig. 3), indicating important influx from Deliblato dune. Dots on the cation triangle characteristic for the central part of the terrain (Ib, IIb, and IIIb) show the shift from non-dominant type to $\mathrm{Na}^{+}+\mathrm{K}^{+}$type (Fig. 3).

Processes, such as cationic exchange and dissolution of mica and Na-feldspars, cause domination of $\mathrm{Na}^{+}$in the deeper groundwaters [17]. Groundwaters from IIa and partially IIIa aquifers belong to a non-dominant type (cation triangle), with characteristics shifting to mixing zone (central diamond). Also, the strong correlation coefficients, as given above, indicate the shifting to non-dominant hydrochemical type, and the stronger influence of $\mathrm{Na}^{+}, \mathrm{K}^{+}$, and $\mathrm{Cl}^{-}$with the depth (Figs $2 \mathrm{~d}$ and 2e). The central part of the study area is characterized by $\mathrm{Na}^{+}+\mathrm{K}^{+}-\mathrm{HCO}_{3}^{-}$type for all three aquifers (Ib, IIb, and IIIb). Central diamond, Fig. 3, shows that all DWs and piezometers from I aquifer and the eastern part of the area indicate temporary hardness, while deeper groundwater shifts through mixing zone to $\mathrm{Na}^{+}+\mathrm{K}^{+}-\mathrm{HCO}_{3}{ }^{-}$type. The plotted $\mathrm{Ca}^{2+}+\mathrm{Mg}^{2+}$ points, compared to total cations (Fig. 4a), fall significantly below the equiline - especially for the deeper aquifers in the western and central parts of the area, reflecting the increased contribution of potassium and sodium in groundwater chemistry. The impact of sodium and 


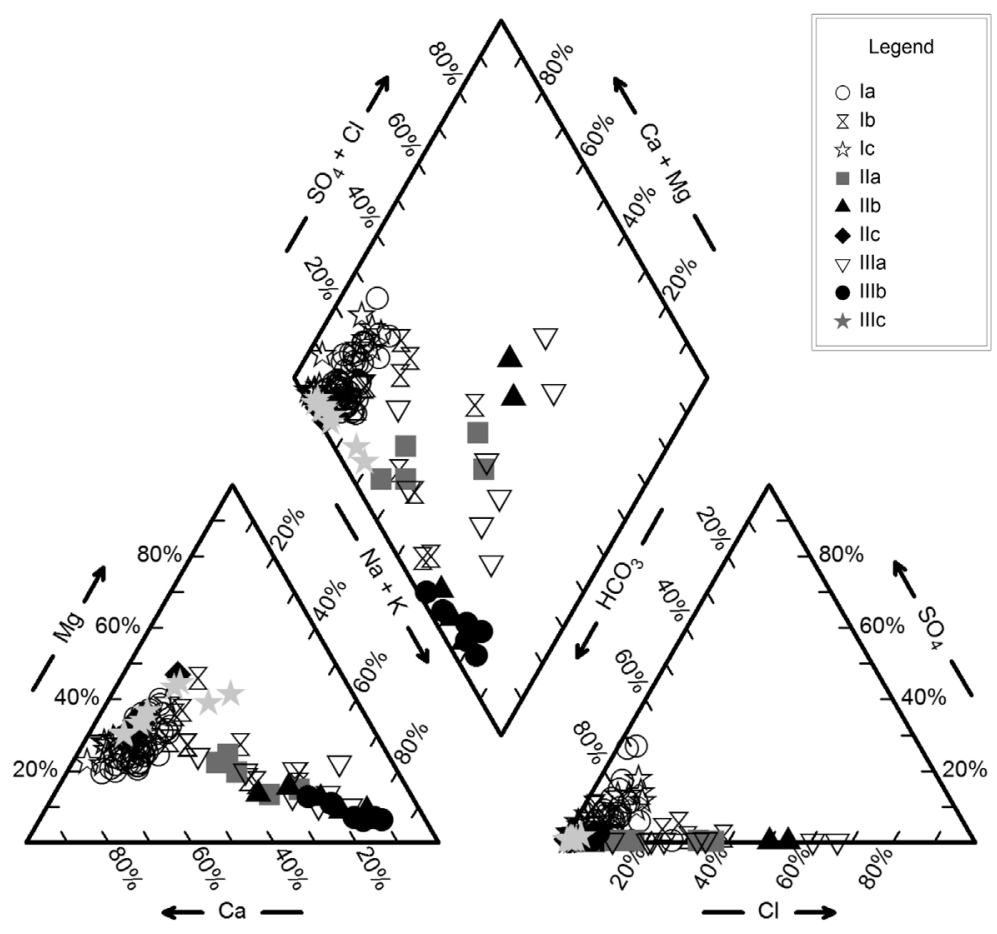

Fig. 3. Piper diagram of geochemical characterization of groundwater in the Kovin-Dubovac depression based on principal cations and anions (meq L ${ }^{-1}$ ).

potassium also increases with depth, as confirmed by Piper plot (Fig. 3) and Pearson correlation coefficients, indicating a shift from $\mathrm{Ca}^{2+}-\mathrm{HCO}_{3}^{-}$to $\mathrm{Na}^{+}+\mathrm{K}^{+}-\mathrm{HCO}_{3}^{-}$ type in the deeper western and central parts of the area (Fig. 2d). In contrast, the plotted points, which represent aquifers in the eastern part of the research area (I-IIIc) fall near the 1:1 line, suggesting the dissolution of calcite and dolomite [18]. In the Kovin-Dubovac area, sulfate concentrations decrease with depth, and in II and III aquifers are usually below detection limit (Table 1). Therefore, sulfate concentrations were excluded from the drawing of plot $\mathrm{Ca}^{2+}+\mathrm{Mg}^{2+}$ versus $\mathrm{HCO}_{3}{ }^{-}+\mathrm{SO}_{4}{ }^{2-}$. Decreasing $\mathrm{SO}_{4}^{2-}$ concentrations with depth (Table 1) are most likely the result of the bacterial mediated process of sulfate-reduction. The plot (Fig. 4b) indicates that the source of $\mathrm{Ca}^{2+}$ and $\mathrm{Mg}^{2+}$ could potentially be carbonate dissolution from loess plateau beyond the study area (Fig. 1b). When solution concentrations of $\mathrm{Ca}^{2+}$ and $\mathrm{HCO}_{3}^{-}$are high enough, calcium carbonate precipitation may occur. Calcite precipitation could be explained with microbial hydrolysis of urea [19]. Since KovinDubovac is an agricultural area and urea is relatively inexpensive, widely available, and easily degradable to carbon dioxide and ammonia, it could be an ideal agent for biogeochemical calcite precipitation in shallow Quaternary deposits.

The excess of $\mathrm{HCO}_{3}^{-}$over $\mathrm{Ca}^{2+}+\mathrm{Mg}^{2+}$ suggests a significant contribution of silicate sources of $\mathrm{HCO}_{3}^{-}$ in the central part of the Kovin-Dubovac depression (Fig. 4b). Also, the low $\mathrm{Ca}+\mathrm{Mg} / \mathrm{HCO}_{3}$ ratio, less than 0.5, in this area, could be the result of $\mathrm{Ca}^{2+}+\mathrm{Mg}^{2+}$ depletion by cation exchange when $\mathrm{Ca}^{2+}$ from groundwater is exchanged with $\mathrm{Na}^{+}$bound in clays. This phenomenon could explain the dominance of $\mathrm{Na}^{+}$and $\mathrm{K}^{+}$ions over $\mathrm{Ca}^{2+}$ and $\mathrm{Mg}^{2+}$ ions at all three aquifers in the central part of the area (Fig. 4c).

In analyzed groundwater samples, $95 \%$ of all samples have a molar ratio $\mathrm{Na} / \mathrm{Cl}$ above 1 (average molar ratio 4.71), which strongly indicates the non-halite source of $\mathrm{Na}^{+}$, and suggests the silicate weathering as a possible source of that cation (Fig. 4d). Ratio $\mathrm{Na} / \mathrm{Cl}$ versus electrical conductivity could be used for identifying the evaporation process [17]. Although plotted dots show that the evaporation process could explain the increase of $\mathrm{EC}$ for relatively constant $\mathrm{Na} / \mathrm{Cl}$ ratios in the shallow aquifer, it cannot be used for deeper ones (Fig. 4e). In deeper aquifers $\mathrm{Na} / \mathrm{Cl}$ ratio increases rapidly, except in the eastern part of II aquifer, where a significant groundwater influx from Deliblato dune exists.

\section{Suitability of Groundwater for Various Purposes}

\section{Quality Assessment for Irrigation Purposes}

Analysis of groundwater shows significant differences between various parts of the research area. Thus, the changes in chemical composition may affect the utility of groundwater for various purposes, which require assurances of different water quality standards. The classification of groundwater for irrigation is summarized in Table 2. 
a)

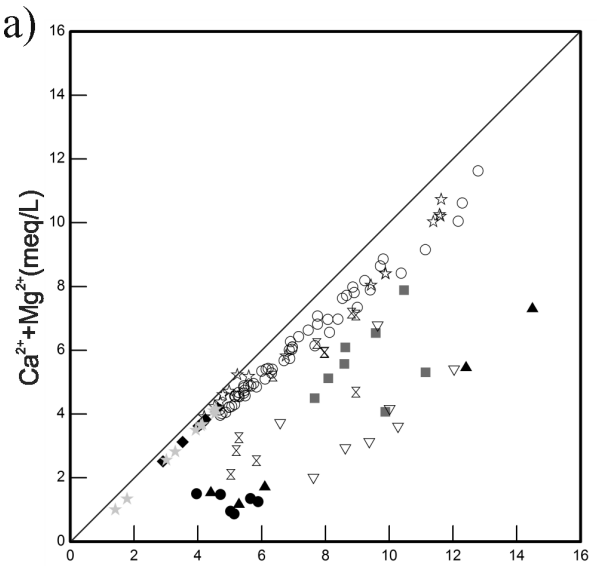

c)

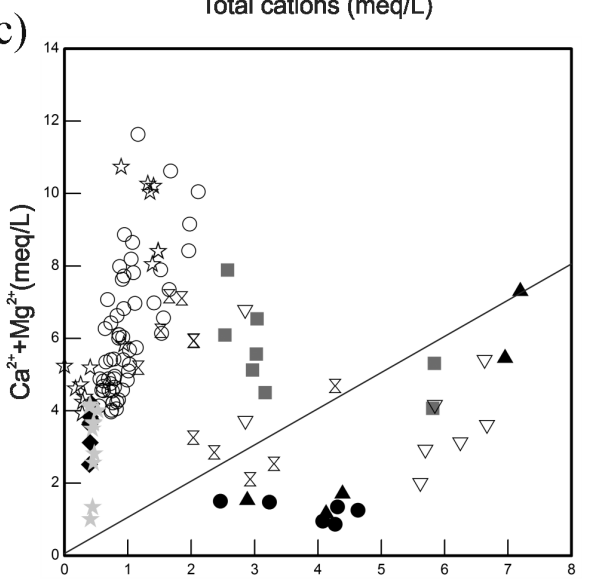

e)

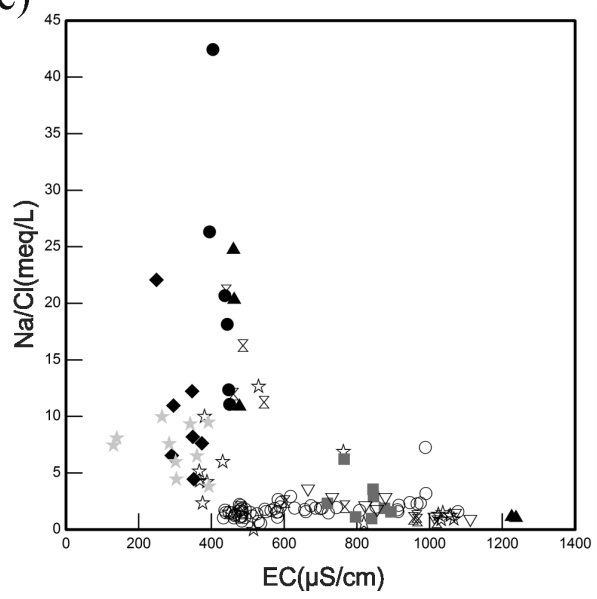

b)

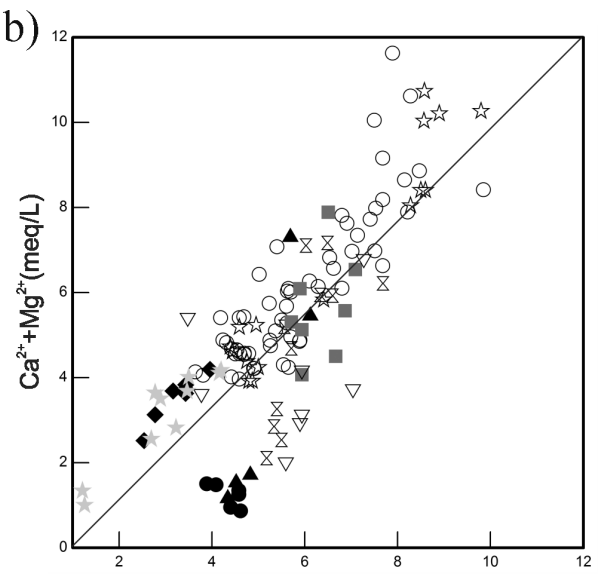

d)

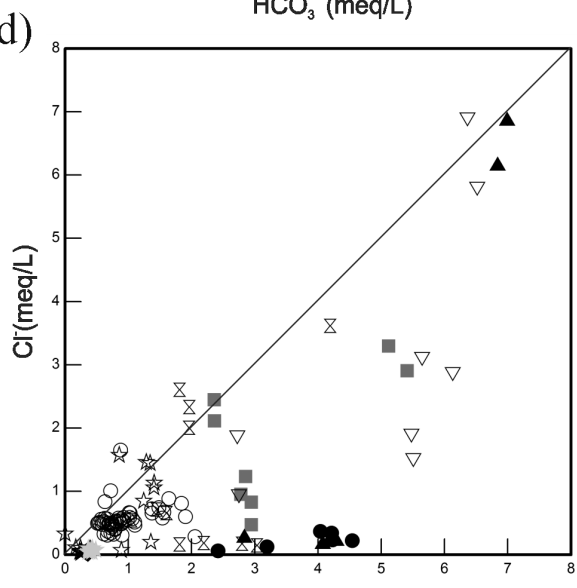

$\mathrm{Na}^{+}(\mathrm{meq} / \mathrm{L})$

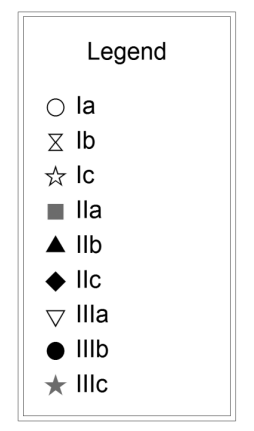

Fig. 4. Plots of ionic relationships for nine established zones: a) $\mathrm{Ca}^{2+}+\mathrm{Mg}^{2+}$ versus total cations, b) $\mathrm{Ca}^{2+}+\mathrm{Mg}^{2+}$ versus $\mathrm{HCO}_{3}^{-}$, c) $\mathrm{Ca}^{2+}+\mathrm{Mg}^{2+}$ versus $\mathrm{Na}^{+}+\mathrm{K}^{+}$, d) $\mathrm{Cl}^{-}$versus $\mathrm{Na}^{+}$, and e) $\mathrm{Na} / \mathrm{Cl}$ versus $\mathrm{EC}$.

Based on the SAR values, the groundwaters from the Kovin-Dubovac area are classified as excellent for irrigation in all three aquifers (Table 2). The percent sodium $(\% \mathrm{Na})$ shows excellent groundwater quality in the eastern part of the study area compared to the western and central parts, where sodium concentrations significantly increased with depth (Fig. 2d). Higher RSC value in water indicates increased adsorption of sodium in soil [20], where soil becomes alkaline and changes to sodic over time, if the water contains noticeable
$\mathrm{Na}^{+}$concentrations. Lower RSC values are recorded in a shallow aquifer in the eastern part of the study area (Table 2).

Additionally, the quality of irrigation water decreases with depth. KR values show a similar trend to RSC. The results are in accordance with increasing sodium concentrations with depth (Table 1) and sodium spatial distribution map (Fig. 2d). Those results were expected, having in mind obtained a graph for the ionic relationship between $\mathrm{Ca}^{2+}+\mathrm{Mg}^{2+}$ versus $\mathrm{Na}^{+}+\mathrm{K}^{+}$(Fig. 4 c). 
MAR values indicate that groundwaters are suitable for irrigation with a slow decrease of water quality in the III aquifer on the east in the zone of the groundwater influx from Deliblato dune.
Generally, the obtained results (Table 2) point out the better groundwater quality for irrigation in the eastern zone. This could lead to an increase in the irrigated area along Kovin-Dubovac as well as contribute to

Table 2. Classification of groundwater for irrigation, water supply or industrial uses based on the common water quality indices.

\begin{tabular}{|c|c|c|c|c|c|c|c|c|c|c|c|}
\hline \multirow[b]{3}{*}{ Parameter } & \multirow[b]{3}{*}{ Range } & \multirow{3}{*}{$\frac{\text { Aquifer }}{\text { Classification }}$} & \multicolumn{9}{|c|}{ Percentage of samples per aquifers } \\
\hline & & & \multicolumn{3}{|c|}{$\mathrm{I}$} & \multicolumn{3}{|c|}{ II } & \multicolumn{3}{|c|}{ III } \\
\hline & & & $\mathrm{a}$ & $\mathrm{b}$ & $\mathrm{c}$ & a & $\mathrm{b}$ & $\mathrm{c}$ & $\mathrm{a}$ & B & $\mathrm{c}$ \\
\hline \multirow{4}{*}{ SAR } & $0-10$ & Excellent & 100 & 100 & 100 & 100 & 100 & 100 & 87.5 & 100 & 100 \\
\hline & $10-18$ & Good & 0 & 0 & 0 & 0 & 0 & 0 & 12.5 & 0 & 0 \\
\hline & $18-26$ & Fair & 0 & 0 & 0 & 0 & 0 & 0 & 0 & 0 & 0 \\
\hline & $>26$ & Poor & 0 & 0 & 0 & 0 & 0 & 0 & 0 & 0 & 0 \\
\hline \multirow{5}{*}{$\% \mathrm{Na}$} & $0-20$ & Excellent & 100 & 27.3 & 100 & 0 & 0 & 100 & 0 & 0 & 80 \\
\hline & $20-40$ & Good & 0 & 36.4 & 0 & 75 & 0 & 0 & 12.5 & 0 & 20 \\
\hline & $40-60$ & Permissible & 0 & 36.4 & 0 & 25 & 40 & 0 & 37.5 & 0 & 0 \\
\hline & $60-80$ & Doubtful & 0 & 0 & 0 & 0 & 60 & 0 & 50 & 66.7 & 0 \\
\hline & $>80$ & Unsuitable & 0 & 0 & 0 & 0 & 0 & 0 & 0 & 33.3 & 0 \\
\hline \multirow{3}{*}{ RSC } & $<1.25$ & Good & 96.4 & 54.5 & 100 & 62.5 & 40 & 100 & 37.5 & 0 & 100 \\
\hline & $1.25-2.5$ & Medium & 3.6 & 27.3 & 0 & 37.5 & 0 & 0 & 12.5 & 16.7 & 0 \\
\hline & $>2.5$ & $\mathrm{Bad}$ & 0 & 18.2 & 0 & 0 & 60 & 0 & 50 & 83.3 & 0 \\
\hline \multirow{3}{*}{$\mathrm{KR}$} & $<1$ & Suitable & 78.6 & 0 & 64.7 & 0 & 0 & 100 & 0 & 0 & 100 \\
\hline & $1-2$ & Marginal suitable & 19.6 & 63.6 & 25.3 & 0 & 0 & 0 & 0 & 0 & 0 \\
\hline & $>2$ & Unsuitable & 1.8 & 26.4 & 0 & 100 & 100 & 0 & 100 & 100 & 0 \\
\hline \multirow{2}{*}{ MAR } & $<50$ & Suitable for irrigation & 100 & 90.9 & 100 & 100 & 100 & 85.7 & 87.5 & 100 & 70 \\
\hline & $>50$ & Harmful for irrigation & 0 & 9.1 & 0 & 0 & 0 & 14.3 & 12.5 & 0 & 30 \\
\hline \multirow{4}{*}{$\mathrm{EC}$} & $<250$ & Low salinity hazard (good) & 0 & 0 & 0 & 0 & 0 & 14.3 & 0 & 0 & 20 \\
\hline & $250-750$ & Medium salinity hazard (moderate) & 82.1 & 54.5 & 58.8 & 12.5 & 60 & 85.7 & 25 & 100 & 80 \\
\hline & $750-2,250$ & High salinity hazard (poor) & 18.9 & 45.5 & 41.2 & 87.5 & 40 & 0 & 75 & 0 & 0 \\
\hline & $>2,250$ & Very high salinity hazard (very poor) & 0 & 0 & 0 & 0 & 0 & 0 & 0 & 0 & 0 \\
\hline \multirow{5}{*}{ LSI } & $-2.0-0.5$ & Serious corrosion & 5.4 & 0 & 0 & 0 & 0 & 0 & 0 & 0 & 0 \\
\hline & $-0.5-0$ & Slightly corrosion but non-scale forming & 46.4 & 72.7 & 17.6 & 0 & 40 & 0 & 12.5 & 0 & 0 \\
\hline & $=0$ & Balanced but pitting corrosion possible & 1.8 & 0 & 0 & 0 & 0 & 0 & 0 & 0 & 0 \\
\hline & $0-0.5$ & Slightly scale forming and corrosive & 30.3 & 18.2 & 70.6 & 12.5 & 0 & 42.9 & 25 & 83.3 & 20 \\
\hline & $0.5-2$ & Scale forming but non corrosive & 16.1 & 9.1 & 11.8 & 87.5 & 60 & 57.1 & 62.5 & 16.7 & 80 \\
\hline \multirow{5}{*}{ RSI } & $<5.5$ & Heavy scale & 0 & 0 & 0 & 0 & 0 & 0 & 0 & 0 & 0 \\
\hline & $5.5-6.2$ & Moderate scale & 1.8 & 0 & 0 & 0 & 0 & 0 & 0 & 0 & 0 \\
\hline & $6.2-6.8$ & Neutral water & 14.3 & 0 & 42.2 & 87.5 & 80 & 14.3 & 25 & 0 & 10 \\
\hline & $6.8-8.5$ & Aggressive water and corrosion is likely & 83.9 & 100 & 58.8 & 12.5 & 20 & 85.7 & 75 & 100 & 90 \\
\hline & $>8.5$ & Very aggressive water and corrosion is possible & 0 & 0 & 0 & 0 & 0 & 0 & 0 & 0 & 0 \\
\hline \multirow{3}{*}{ AI } & $>12$ & Water is non-aggressive & 19.6 & 19.2 & 23.5 & 100 & 60 & 85.7 & 87.5 & 50 & 90 \\
\hline & $10-11.9$ & Water is moderately aggressive & 80.4 & 81.8 & 76.5 & 0 & 40 & 14.3 & 12.5 & 50 & 10 \\
\hline & $<10$ & Water is very aggressive & 0 & 0 & 0 & 0 & 0 & 0 & 0 & 0 & 0 \\
\hline
\end{tabular}


the achievement of WMP projections and needs for increased irrigation.

\section{Quality Assessment for Water Supply and Industrial Purposes}

Examination of groundwater suitability for human consumption requires a comparison of quality parameters with the Serbian drinking water standard [21]. Additionally, only a few collected samples exceed the maximum permitted concentrations of major ions (1.6\% samples exceed permitted $\mathrm{Na}^{+}$concentration of $150 \mathrm{mg} \mathrm{L} \mathrm{L}^{-1}, 2.3 \%$ for $\mathrm{K}^{+}$concentrations of $12 \mathrm{mg} \mathrm{L}^{-1}$, and $3.1 \%$ for permitted chloride content of $200 \mathrm{mg}$ $\mathrm{L}^{-1}$ ), whereas all other ions, calcium, magnesium and sulfate, comply with the requirements set by the Serbian standard. Based on the established maximum permitted values, the analyzed groundwaters are considered to be suitable for drinking. Bicarbonate, total dissolved solids, and total hardness currently do not have established values on the national scale.

As corrosion and scaling are common problems found in water supply and industrial systems, various indexes can be used to predict the water tendencies to precipitate or dissolve $\mathrm{CaCO}_{3}$, and therefore as the main parameters in determining water aggressiveness [22]. Based on LSI, RSI, and AI values, groundwaters are classified as moderately aggressive to aggressive. All the above indices are designed to indicate the tendency of given waters to deposit scales on metal substrates and surely not to predict the absolute corrosivity of waters.

\section{Conclusions}

Considering the over-exploitation of groundwaters in the northern part of the Banat region, unsuitable drinking water quality and contamination of the drainage channels, analyzing groundwater origin in the south Banat region and its quality for multipurpose use was crucial.

Geological and hydrogeological complexities of the study area have an impact on the groundwater quality and chemical composition, which is reflected in vertical and spatial zonation. Based on the attempt made to study the quality of groundwaters, it was found that hydrochemical facies shifted from $\mathrm{Ca}^{2+}-\mathrm{HCO}_{3}^{-}$to $\mathrm{Na}^{+}+\mathrm{K}^{+}-\mathrm{HCO}_{3}^{-}$in the central part of the area. Obtained results suggest vertical mixing of shallow groundwaters with deeper ones, most likely due to lack of aquitard and eroded or cracked coal seams in the central part of the Kovin depression. The eastern part of the area shows the groundwater recharge from Deliblato dune direction. Results of chemical research indicate good stratification and vertical seclusion of the aquifers in the western part of the study area (Field A). Generally, groundwaters show significant exploitation potential for different purposes, but the potential for water supply and irrigation decreasing with groundwater depth. Due to mixing and an increase of some ions which are not desirable in elevated concentrations, the groundwaters from the central part of the area should be avoided for exploitation. Problems with corrosion could be avoided by using corrosion-resistant materials. On the other hand, in the vicinity of lignite exploitation the use of protective agents and fertilizers in agriculture (diffusion pollution) increase pressures on groundwater quality. Thus, further research should focus on some of the other parameters that could impact human health or indicate a degradation of groundwater resources.

\section{Acknowledgements}

The authors express their gratitude to the Serbian Ministry of Education, Science and Technological Development for funding project No. TR37014.

\section{Conflict of Interest}

The authors declare no conflict of interest.

\section{References}

1. IGRAC. Groundwater Overview: Making the invisible visible, The Netherlands: International Groundwater Resources Assessment Centre; 2018. Available online: https://www.un-igrac.org/sites/default/files/resources/files/ Groundwater\%20overview\%20-\%20Making\%20the\%20 invisible\%20visible_Print.pdf (accessed on 24 July 2018).

2. DIMKIĆ M., STEVANOVIĆ Z., ĐURIĆ D. Utilization, Protection and Status of Groundwater in Serbia. Proceedings of Regional IWA Conference "Groundwater Management in the Danube River Basin and Other Large River Basins"; Belgrade, 83, 2007.

3. MARIĆ N., MRAZOVAC KURILIĆ S., MATIĆ I., SORAJIĆ S., ZARIĆ J. Groundwater quality on the territory of Kikinda municipality (Vojvodina, Serbia). Environ. Earth Sci., 72, 525, 2014.

4. DJURIC D., JOSIPOVIĆ J., JEVTIC G., SLIMAK T., PUSIC M. Groundwater management in Vojvodina. Water Pract. Tech., 2 (3) wpt2007061, 2007.

5. WATER MASTER PLAN (WMP) The Water Master Plan of the Republic of Serbia, Ministry of Agriculture, Forestry and Water Resources Management, Belgrade: Republic of Serbia 2002 [In Serbian].

6. BABIĆ MLADENOVIĆ M., RADOVANOVIĆ M., RADOSAVLJEVIĆ P. Monitoring of the Iron Gate Hydropower and Navigation System on the Danube River. Water Research and Management, 1 (3), 3, 2012.

7. MITROVIĆ D., ĐOKOVIĆ N., ŽIVOTIĆ D., BECHTEL A., ŠAJNOVIĆ A., STOJANOVIĆ K. Petrographical and organic geochemical study of the Kovin lignite deposit, Serbia. Int. J. Coal Geol., 168 (1), 80, 2016.

8. DEVIC G., DJORDJEVIC D., SAKAN S. Natural and anthropogenic factors affecting the groundwater quality in Serbia. Sci. Total Environ., 468-469, 933, 2014.

9. SHAHAB A., SHIHUA Q., RASHID A., UL HASAN F., SOHAIL M.T. Evaluation of Water Quality for Drinking and Agricultural Suitability in the Lower Indus Plain in 
Sindh Province, Pakistan. Pol. J. Environ. Stud., 25 (6), 2563, 2016.

10. RAKIĆ M. Geology of the sheet Bela Crkva, L 34-115, Belgrade: Geological Institute. 1978 [In Serbian].

11. JOSIPOVIĆ J., SORO A. Groundwaters of Vojvodina, Belgrade: Jaroslav Černi Institute for the Development of Water Resources, 97, 2012 [In Serbian].

12. STOJANOVIĆ K., ŽIVOTIĆ D., ŠAJNOVIĆ A., CVETKOVIĆ O., NYTOFT H.P., SCHEEDER G., Drmno lignite field (Kostolac Basin, Serbia): origin and palaeoenvironmental implications from petrological and organic geochemical studies. J. Ser. Chem. Soc., 77 (8), 1109, 2012.

13. JEVTIĆ G., ZORIĆ M. Hydrogeological model of underwater coal mine project at Kovin. In: Proceedings of XIV Serbian hydrogeological Symposium, Zlatibor, Serbia, 271, 2012.

14. MATENCO L., RADIVOJEVIĆ D. On the formation and evolution of the Pannonian Basin: Constraints derived from the structure of the junction area between the Carpathians and Dinarides. Tectonics, 31 (6), TC6007, 2012.

15. MAJKIĆ-DURSUN B., TONČIĆ J., PETKOVIĆ A., ČOLIĆ J. Redox conditions and groundwater quality issues of selected alluvial aquifers in Serbia. Wa. Sci. Technol., 16 (4), 1086, 2016.

16. AMERICAN PUBLIC HEALTH ASSOCIATION (APHA), Standard methods for the examination of water and wastewater, $21^{\text {st }}$ edn, Washington: American Public Health Association, 2005.
17. MRAZOVAC S., VOJINOVIĆ-MILORADOV M., MATIĆ I., MARIĆ N. Multivariate statistical analyzing of chemical parameters in groundwater in Vojvodina. Chem. Erde-Geochem., 73, 217, 2013.

18. TIWARI A.K., SINGH A.K. Hydrogeochemical Investigation and Groundwater Quality Assessment of Pratapgarh District, Uttar Pradesh. J. Geol. Soc. India., 83, 329, 2014.

19. ZHU T., DITTRICH M. Carbonate Precipitation through Microbial Activities in Natural Environment, and their Potential in Biotechnology: A Review. Front. Bioeng. Biotechnol., 4 (4), doi:10.3389/fbioe.2016.00004, 2016.

20. PATEL P., JANARDHANA RAJU N., SUNDARA RAJA REDDY B.C., SURESH U., GOSSEL W., WYCISK P. Geochemical processes and multivariate statistical analysis for the assessment of groundwater quality in the Swarnamukhi River basin, Andhra Pradesh, India. Environ. Earth Sci., 75 (611), 1, 2016.

21. OFFICIAL GAZETTE FRY. Regulation on the Hygienic Adequacy of Drinking Water, No. 42/98, 44/99, Belgrade 1999 [In Serbian].

22. RAVIKUMAR P., SOMASHEKAR R.K. Assessment and Modelling of Groundwater Quality Data and Evaluation of Their Corrosiveness and Scaling Potential Using Environmetric Methods in Bangalore South Taluk, Karnataka State, India. Water Resour., 39 (4), 446, 2012. 